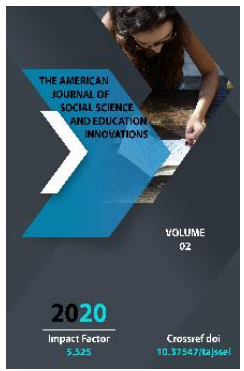

Journal Website: http://usajournalshub.c om/index,php/tajssei

Copyright: Original content from this work may be used under the terms of the creative commons attributes 4.0 licence.

\section{About The Largest Stupa Or Zurmala Monument In North Bacteria}

Khalikov Eshboltaevich Zokir

(Phd) Associate Professor Of Termez State University, Uzbekistan

Toshkobilov Bobur Kholbutaevich

Master's Student Of Termez State University, Uzbekistan

\title{
ABSTRACT
}

The article deals with the results of archeological researches in and around Zurmala Buddhist stupa, which belongs to the category of Old Termez monuments of Surkhandarya oasis in the southern part of Uzbekistan based on written sources.

\section{KEYWORDS}

Old Termez, Zurmala monument, Buddhist stupa, Excavations, archeological finds, Kushan kingdom, coins, pottery, Kanishka, Vasudeva, Khuvishka

\section{INTRODUCTION}

One of the priorities of the policy pursued in the country in the conditions of independence of the people of Uzbekistan and for the development of local and foreign tourism is to conduct archeological research, restore and conserve archeological and architectural structures in our country. The issue of their museumization is more important than ever.

\section{MATERIALS AND METHODS}

Excavations in the study of Buddhist temples, stupas and their surroundings, built during the reign of the Kushan kingdom, which are important in showing the peculiarities of the Buddhist culture preserved on the southern borders of our country Archaeological evidence, numismatic materials, pottery, stone, bronze, various ancient artifacts made of copper were used.

\section{RESEARCH RESULTS}

In the territory of Eski Termez, the southern border of Uzbekistan, the construction of religious and secular architectural structures of Buddhist culture became widespread during the Kushan dynasty. The study of 
Buddhist temples such as Koratepa, Fayoztepa, Zurmala and archeological monuments such as Ayritom, Dalvarzintepa and Kholchayon, in particular, confirms our opinion that they are world famous. Their scientific recognition not only led to the spread of Buddhism in the northern and eastern regions, but also to the period of the Kushan Kingdom of Uzbekistan.

(Pugachenkova G.A., Rtveladze EV Severnaya Bactria Tokharistan.T .: 1990.str.85). The first information about the monuments of Buddhist culture of Northern Bactria in the Kushan period can be found in the diaries of the Buddhist priest Xuan Jian, who visited Termez and Chaghaniyan from Chanan (now Xi'an), China in 629-630. (Midzutani, 1971). According to the Buddhist priest, Tami has more than 10 monasteries in Termez and more than 1,000 monks. It is mentioned here that there are many miraculous stupa and examples of Buddhist sculptures carved out of stone. However, more convincing scientific data were obtained in $1926-1928$ by A.S. Strelkov, a member of the Termez expedition by the Oriental Museum of Moscow and the Hermitage Museum of St. Petersburg, based on Chinese tourist data. noted the similarity (Strelkov A.S. 1928/1929).

Shortly afterwards, M.E. Masson organized an expedition to the Termez archeological complex and began to study the monuments of Termez and its environments. In these archeological researches the general features of Zurmala monument were studied. TAKE The characteristics of all monuments located in and around Termez and built of raw bricks were studied (Zhukov, 1941).

The Zurmala monument is located on the east side of Old Termez. The expansion of the city in an easterly direction during the reign of the Kushans and the appearance of a large Buddhist stupa on its eastern side confirm that the importance of Buddhism in Northern Bactria certainly increased.

The cylindrical construction of the monument and the home-shaped appearance of the tower, as well as its erection on a stepped high foundation, resemble the Hadda Stupa in eastern Afghanistan, surrounded by stone tiles depicting Buddhist images. (Pugachenkova G.A., Rtveladze E.V. Severnaya Bactria-Toxaristan.T: 1990.str. 83-96) In 1964, G.A. Pugachenkova (Pugachenkova G.A., 1967, Imamura, 2017) conducted research at the Zurmala monument. Archaeological research is mainly focused on two aspects: first, if it is aimed at studying the foundation of the monument by digging a trench on the northwestern and south-western sides of the Zurmala stupa; second, 500 meters from the monument

was aimed at collecting materials found in the upper layer in the radius. The brick sides of the stupa are $32 \times 33$, with a thickness of $11-12 \mathrm{~cm}$. The size and shape of the Zurmala stupa is exactly the same as the buildings of the Kushan kingdom of Bactria. In addition, excavations at three sites of the stupa revealed that the foundation of the monument was rectangular and measured 22 $x 16$ meters. . Finding fragments of limestone blocks and cornices around the Zurmala stupa confirms that the perimeter of the foundation of the monument is covered with a sheath made of embossed limestone, or that there is another Buddhist architectural structure around it. Based on these conclusions, the expedition led by Sh.R.Pidaev and K.Kyudzo began to study the Buddhist stupa in the 
Surkhandarya oasis and recognized the period of Kanishka I in the II century BC as a period of spread of Buddhism from northern India to eastern Turkestan (Pidaev Sh.R. Buddhism and Buddhist heritage in Uzbekistan.T: 2010; Kato 1997; Kato 2002). In 2012, T. Annaev and students of Termez State University found several archeological artifacts related to the Zurmala stupa. These artifacts were found near a large pool 400 meters south of the monument (Abdullaev K., Annaev T. 2012). While these sculptural specimens are called successive donors, some archaeologists call them priests. After all, these sculptures are relief-shell ornaments of the stupa foundation or works of art placed on the porch shelves around the stupa. The 2019 Archaeological Season From August 27 to September 17, archeological excavations were carried out around the Zurmala Buddhist stupa.

In the north-eastern pit, when the depth reached 1.96 meters, a metal rod, a bronze coin (Kanishka II) and thin-walled, red angob jars, flanges of barrels, fragments of lamps were found. At a depth of two meters in the pit, a layer of clean clay soil began, and no finds were found in this layer. On its southern side alone, at a depth of $1.96 \mathrm{~m}$, there is still a cultural layer. The depth of the pit in this section is $2.90 \mathrm{~m}$. The pit consists of layers of ash, sand and soil with a thickness of $60 \mathrm{~cm}$, starting from $2.35 \mathrm{~m}$. It was in this layer that a piece of pottery depicting a snake's head was found. The lowest layer of the northeastern shurf consists of continental clay soil and sandstone. The foundation of the monument is built on this solid layer. The distance between Shurf and Zurmala stupa is 50 meters. In addition, on the south-eastern side of the Stupa, $4 \times 2$ square meters. a second pit of size was thrown. In the 2018 season, fragments of various Kushan and medieval pottery were found in a trench $(10 \times 2 \mathrm{~m})$ opened on the southwest side. Therefore, a $2 \times 2$ meter trench was dug in the south-east. On the east side, at a distance of 50 meters from the Zurmala stupa, two ditches measuring $4 \times 2$ meters were excavated. They are called " $A$ " and " $B$ " below. From the agrotechnical treatment when the depth of the pit "A" reaches 1 meter the compacted layer ends. In this layer springs of several pottery and a jar of glassware, a piece of candlestick were found. A well-preserved bronze coin (Kanishka I) was found when the pit reached a depth of 2.50 meters. Below we provide information about the types of archeological objects found around the Zurmala stupa and their characteristics. Bronze coin. It was tattooed during the reign of Kanishka II.It was kept well. It is $2.2 \mathrm{~cm}$ the diameter of coin and weighs $17.5 \mathrm{~g}$. It was found in a northeastern pit, $2.30 \mathrm{~m}$ deep from the rapper. Tanga. Bronze. It was tattooed during the reign of Kanishka II. The standing position of the ruler on the right,

on the reverse side there is an image of the Indian god Shiva and the bull "Zebu". The bronze coin is $2 \mathrm{~cm}$ in diameter and weighs 9.5 g. On the right can be seen the standing position of the ruler. Ceramic pot flange. The lion's head is depicted. Quality baked from light yellow pure clay. The flange of the vessel is turned inwards, the shape is semi-spherical, the wall is very thin and smooth. Painted in red angob on the inside and outside. The vessel is typical for the II-III centuries. Metalware. Dimensions $2.7 \times 1.2 \mathrm{~cm}$. It weighs $6.3 \mathrm{~g}$. A piece of metal. It is $8.5 \mathrm{~cm}$ long and 2.5 $\mathrm{cm}$ wide. Shape spear-shaped. Glassware. Dimensions $3 \times 2 \mathrm{~cm}$. A piece of glassware. $4 \times$ $3.7 \mathrm{~cm}$. The green surface is white. Glass 
balloon. Diameter $1.5 \mathrm{~cm}$. Weight $5.2 \mathrm{~g}$. A piece of jewelry.

A piece of metal plate. The upper part is covered with golden water. One end is flattened and the other end is broken. The level of preservation is good.

\section{CONCLUSION}

Termez State University in collaboration with Rishsho University of Japan has been conducting archeological research around the famous Buddhist monument of the Kushan period, Zurmala Stupa, since 2018. It has been 90 years since the study of the Zurmala monument began. But Zurmala's survival rate and the risk of its collapse are increasing. Since 2017, an attempt has been made to identify the architectural structures of the monument and its surroundings by collecting photographs, using drones and with an underground detector. Archaeological excavations are being carried out as a result of this research The discovery of bronze and copper coins minted during the reign of the Kushan kings indicates the existence of architectural structures around the Zurmala monument. But so far no remnants or traces of construction have been found. We think it is expedient to further expand the scope of excavations in the coming season.

\section{REFERENCES}

1. Strelkov A.S., 1928- 1929, Pamyatniki Termeza, p. 219-220.

2. Zhukov V.D., Kirpich iz razvalin Starogo Termeza. TAKE., 1-chast., Institut istorii, yazyka i literatury. UzAn SSR., Tashkent. 1936.

3. Pugachenkova G.A. Two stupes on the south of Uzbekistan, Soviet archeology.M., 1967, p.3.
4. Pugachenkova G.A., Rtveladze E.V. Severnaya Bactria-Toxaristan.T: 1990.str. 83-96.

5. Abdullaev K., Annaev T.J. Novaya nakhodki buddiyskie skulptury $v$ okruge Zurmaly.T. Archeology of Uzbekistan, 2012., № 4.

6. Ivamoto Atsushchi.Obzor prezhnyx $\mathrm{i}$ napravleniy novyx issledovaniy stupy Zurmaly // Kushanskoe tsarstvo i stupa na yuge Uzbekistana. Japan University Rishsho.2017.

7. Xalikov Z.E., Imomov E. Iz istorii poyavleniya $\mathrm{v}$ drevney Baktrii monetdeneg i denejnogo obrashcheniya.// Vector razvitii ekonomike i finansov na sovremennom etape.Mejdunarodnaya nauchno-prakticheskaya kon-ya 6-9 dekabrya 2018g. Sochi.str.17-20.

8. Yusupovich, K. S. (2020). The Emergence Of Religious Views Is Exemplified By The Southern Regions. The American Journal of Social Science and Education Innovations, 2(10), 143-145. 8..Isarov U. I. Reviews of Bactrian irrigation system in the bronze age //Ўтмишга назар журнали. - 2019.

9. Isarov U. I. Reviews About Early Nomads In Central Asia //The American Journal of Interdisciplinary Innovations and Research. - 2020. 